\title{
Comparison of three Gobiidæ (Teleostei) life history strategies over their geographical range
}

\author{
Jean-Luc BOUCHEREAU*, Olivier GUELORGET \\ Laboratoire d'Hydrobiologie Marine et Continentale (UMR-CNRS 5556), Université Montpellier II, Sciences et \\ Techniques du Languedoc, case courrier 093, Place Eugène Bataillon, 34095 Montpellier Cedex 05, France.
}

(Received 27/08/96, revised 11/06/97, accepted 04/07/97)

\begin{abstract}
This article summarizes the latest knowledge on the ecology of three gobies. The authors compile data published by various scientists who carried out their research under different conditions, using a variety of methods for collecting data and processing the results. The relationship between population structure and different environmental conditions was considered for three goby species Pomatoschistus minutus (Pallas, 1770), P. microps (Krøyer, 1838) and Gobius niger Linnaeus, 1758, in different geographical areas, notably the Mediterranean (Gulf of Lions and Adriatic) and cold temperate Atlantic (north of the English Channel) parts. In the three species, the life cycles in the Mediterranean, favoured by the local hydroclimate, are "contracted" (growth is rapid and reproductive effort emphasized) whereas, in the Atlantic, life cycles are "protracted" with growth and reproduction equivalent or less intense. Irrespective of the geographical location of the species, its reproductive success is very much same. $\mathcal{C}$ Elsevier, Paris
\end{abstract}

\section{gulf of Lions / Atlantic / life cycle / occupying strategy / Gobiidæ}

Résumé - Comparaison biogéographique des paramètres biotiques de trois Gobiidés (Teleostei). Cet article résume les connaissances sur l'écologie de trois gobies. Les auteurs compilent les données publiées par divers chercheurs qui ont entrepris leurs études sous différentes conditions en utilisant une variété de méthodes d'échantillonnage pour la récolte et le traitement des données. Les interrelations entre les variables et les processus démographiques des espèces étudiées, Pomatoschistus minutus (Pallas, 1770), P. microps (Krøyer, 1838) et Gobius niger Linnaeus, 1758, et les conditions environnementales des milieux qu'elles occupent sur la majeure partie de leurs aires de répartition biogéographique sont considérées; les secteurs Méditerranée (golfe du Lion, Adriatique) et Atlantique tempéré froid (au nord de la Manche) sont plus particulièrement pris en compte. Les populations des trois espèces, favorisées par l'hydroclimat local, présentent en Méditerranée un cycle vital tendant vers sa «contraction » durant lequel la croissance est rapide et l'effort reproducteur accentué, alors que celui-ci est plutôt « dilaté » chez celles vivant en Atlantique, avec une croissance et une reproduction relativement égales ou moins intenses. Quelle que soit la position géographique de l'espèce, le succès reproductif reste très voisin. (C) Elsevier, Paris

golfe du Lion / Atlantique / cycles vitaux / stratégies d'occupation / Gobiidæ

\section{INTRODUCTION}

There are over 2000 nominal species of gobies, 81 of them found in the North-East Atlantic and Mediterranean areas $[2,19,71,98,99,100]$. These small fish are known for their great ecological diversity [69] in coastal, estuarine and lagoonal areas. Pomatoschistus minutus (Pallas, 1770) and P. microps (Krøyer, 1838) can be considered as boreal relicts according to their geographical distribution. Gobius niger Linnaeus, 1758 has a temperate Atlantic-Mediterranean origin, and is widely distributed from Norway to the Mediterranean. These three

\footnotetext{
* Correspondence and reprints
} 
gobies are sympatric around the Iberian Peninsula and on the north-western coasts of the Mediterranean. In the past, the biology and ecology of $P$. minutus, $P$. microps and $G$. niger were known only from North Atlantic studies. The strategies and adaptations in estuarine and coastlagoonal environments from the Mediterranean shores were never thoroughly studied before the late eighties. These small fish eat meiofaunal prey, are nest guarders, and migrate over short distances.

In the present study, we propose, on the basis of data published by various scientists who carried out their research under different conditions, using a variety of methods for collecting data and processing their results, to compare the ecology of $P$. minutus, $P$. microps, and $G$. niger, taking account of both the Mediterranean and Atlantic areas of their distribution.

\section{LAGOON DESCRIPTION}

The three goby species were studied in the Mauguio lagoon, located on the French Mediterranean coast, south of Montpellier between $43^{\circ} 33^{\prime} 30^{\prime \prime}$ and $43^{\circ} 37^{\prime} 17^{\prime \prime} \mathrm{N}$ and between $3^{\circ} 57^{\prime} 50^{\prime \prime}$ and $4^{\circ} 05^{\prime} 00^{\prime \prime}$ E. Gobies caught with other fish by fishermen with fixed nets are landed daily at Cabanes de Pérols, near Mauguio lagoon. A sample was collected weekly from 1986 to 1990 to study the demographic structure, and a subsample of 5 individuals per size class was used to study the biotic parameters. Details of the methods employed can be found in Bouchereau [6]. The Mauguio lagoon is shallow (mean $0.80 \mathrm{~m}$ ), with a surface area of $31.66 \mathrm{~km}^{2}$, and is separated from the sea hy a one-kilometre wide stretch of land (lido) except for a passage $1050 \mathrm{~m}$ long, $10 \mathrm{~m}$ wide and $1.50 \mathrm{~m}$ deep. The water temperature is closely related to the temperature of the air [8], mean monthly values lying between $5{ }^{\circ} \mathrm{C}$ (exceptionally $3{ }^{\circ} \mathrm{C}$ ) in January and $25{ }^{\circ} \mathrm{C}$ in July or August. Although winters are usually mild, low temperatures in mid-January can cause the water to freeze in the lagoon. The environment is subject to high spatio-temporal variations of chemical-physical conditions. Northnortheast winds (Mistral and Tramontane), and winds from the south-southeast $\left(120^{\circ}-159^{\circ}\right)$ contribute to the instability of the lagoon water. Windy episodes reaching 8 metres per second are frequent all year round but mainly during April, August and November; however there are high interannual variations. Water circulation is complex and depends upon various factors $[17,81,84]$. These high winds cause brief differences in depth (aeo- lian tides), between the lagoon's northern and southern shores, greater than those of the normal semi-diumal lides and due to possible barometric tides. Runoff from often torrential rains enriches the lagoon environment with nutritional elements, promoting primary production $[47,82]$ which is seven to ten times greater than that of the sea. The meiobenthos can be found in almost unlimited quantities. According to Hénard and Vaulot [47], the lagoon's water volume, estimated at $31.6 \times 10^{6} \mathrm{~m}^{3}$, is renewed, on average, every three months. Green algae of the Ulva, Ulvopis, Chatomorpha, Enteromorpha genera and red algae such as Gracilaria verrucosa grow vigorously from the beginning of spring until summer, invading all water depths [21]. This proliferation can generate an algal overgrowth reaching, for example, $9400 \mathrm{~g} / \mathrm{m}^{2}$ of fresh wet algae in the neighbouring lagoon of Prévost [85], and is responsible for a dystrophic crisis of varying intensity called "malaigues" in the Languedoc area, which can lead to the massive disappearance (death or departure) of marine life such as occurred in August 1988 $[8,11,13,82]$ and in August 1992 [6]. The overall biomass is at its minimum from September to February. Several bird species, potential predators of fish, are permanently present in the Languedocian lagoons. In the Mauguio lagoon, 71 species of fish have been recorded $[82,8]$. Fishing is an intervening factor in the structure and the evolution of their populations. The dominant species caught between 1986 and 1989 were the following, in decreasing order: eels, mullets, sand-smelts, gobies, flat fish and sardines. Halieutic production has declined significantly since $1970[8,82]$, mainly as a result of the modernization of fishing methods (motor-boats, rot-proof fishing nets) and the non-observance of fishing regulations (limited number of fixed nets called capéchades per fisherman) and consequent over-exploitation of the lagoon. However, there has also been a degradation of the lagoon water quality.

\section{DESCRIPTION OF THE SPECIES}

The three goby specics studicd here are small in shore epi- and cryptobenthic teleostean fish, in which males are the nest-keepers. One or several females lay their eggs in the interior of an empty inverted lamellibranch valve (P. minutus and $P$. microps), or on a rock surface (G. niger).

$P$. minutus, the sand goby, is a small fish (maximum size, $\mathrm{TL}, 89 \mathrm{~mm}$ in the Mediterranean [12, 14], essentially 
near the shore, common in the north-eastern Atlantic from Norway to the south of Spain, in some sectors of the western Mediterranean (Gulfs of Lions and Genoa), in the Adriatic (Venice Gulf) and along western Black Sea coasts. The precise geographical distribution of this fish is difficult to define because it has been often mistaken for other goby species $[30,37,38,92,95,96,103]$. $P$. minutus lives in estuaries, saline lagoons, and littoral shores down to $26 \mathrm{~m}$ depth [52]. This goby does not generally remain on a permanent basis in the lagoons or estuaries, but leaves to reproduce in the open sea. This species, over its whole distribution area, does not seem to be commercially fished, but is incidentally caught in abundance in the French Mediterranean lagoons [83], mainly during autumn and winter. Over 40 studies refer to the biology of $P$. minutus from the Atlantic: in the Mediterranean, among Gourret [36], Mathias and Dolique [64], Lo Bianco [62]; Ninni [77], Cavinato [16], Padoa [79] and Hervé [48], only the latter considers its biology. A special feature is that it is the only annual species in the environment studied to understake reproductive (named genesic) and ontogenic lagoon-sea migration. $P$ minutus is very interesting because of its subresident position between long living migratory fish such as soles, sea bream, sea-bass, and gilt-head sea bream, which occupy the lagoon in their first or second year of life, and sedentary species. Both $P$. microps and $G$. niger spend their life cycle in the lagoon, although they are not lagoonal endemics.

P. microps, the common goby, is a small fish (TL: $64 \mathrm{~mm}$ on British coasts, [53] $53 \mathrm{~mm}$ in the Mediterranean, [9]), and is found usually on the Atlantic coasts from Norway to Morocco [70]. In the Mediterranean, its presence is limited from the Gulf of Lions to Corsica. Throughout its distribution area, it lives in estuaries, saline lagoons and along the sea shore down to $11 \mathrm{~m}$ depth in the Atlantic [53]. Although in some parts of the Atlantic, this fish is migratory, it is sedentary in the Gulf of Lions. It is not commercially captured but may be caught locally by fishermen seeking other species. Although studies on the biology of $P$. microps are numerous in northern Europe (over 34; see Webb [104] and Al Hassan et al. [1] for genetic studies of this species), only one study has provided data on this fish biology in the Mediterranean [48].

G. niger is a larger fish than both the Pomatoschistus species previously mentioned (TL: $165 \mathrm{~mm},[28]$ ) and its geographical distribution area is very wide [70]. It occurs from Norway to Mauritania and throughout the Mediterranean and Black Seas. It is often caught in the sea down to $75 \mathrm{~m}[26,70]$, as well as in lagoons and estuaries. This fish is quite sedentary in its distribution but gathers in coastal waters at spawning time and moves in the circalittoral muds in winter [27]. The males watch over the eggs deposited on inert substrates usually provided by rocks. In some areas, this goby is subject locally to commercial fishing and represents, as in the Middle Adriatic, the principal catch of fishing boats working on some occasions at $35 \mathrm{~m}$ depth [26]. Comparatively few studies have becn devoted to this species. For the Mediterranean, growth [28], feeding [22, 26], and reproduction, along with embryogenesis and fecundity [3] have been studied briefly. For the Atlantic, Nash [75] and Vesey and Langford [101] each studied the main aspects (age, growth, reproduction) of $G$. niger biology; Le Menn [61] discussed the vitellogenesis. Benharrat et al. [5] and Benharrat [4] studied enzyme polymorphism of marine and lagoon populations of $G$. niger in the Gulf of Lions, where it is of erratic occurrence.

\section{RESULTS AND DISCUSSION}

\subsection{Growth and life cycle}

The Mediterranean (Mauguio lagoon) and Atlantic populations of $P$. minutus and $P$. microps present noticeable differences in age and linear growth (figures 1,2). In fact, for both spccics, growth takes 12 to 14 months in the Mediterranean (maximum longevity), and up to 22 months and more in the Atlantic. Nlthough spawning occurs later, Atlantic specimens with adequate growth can reach, before winter, sizes equalling or greater than those observed in the Mediterranean. Final growth performance is always better in the Atlantic (tables $I$ to $I I I$ ). The winter period in the Mediterranean has little or no effect on growth, whereas this is notably retarded among $P$. minutus and $P$. microps in the Atlantic. On the other hand, in the Mediterranean (Mauguio lagoon), a slowing down of growth can be found during summer for both these species. In the Mediterranean, most of the growth of $P$. minutus takes place between two winter (and spawning) periods, whereas for $P$ minutus (in the Atlantic) and $P$. microps from both areas, growth is stopped or slowed-down during winter. Males are generally bigger than females in Mediterranean as well as in the Atlantic (tables II, III; figures 3,4). The possibility of a sex difference in growth pattern cannot be ruled out. 


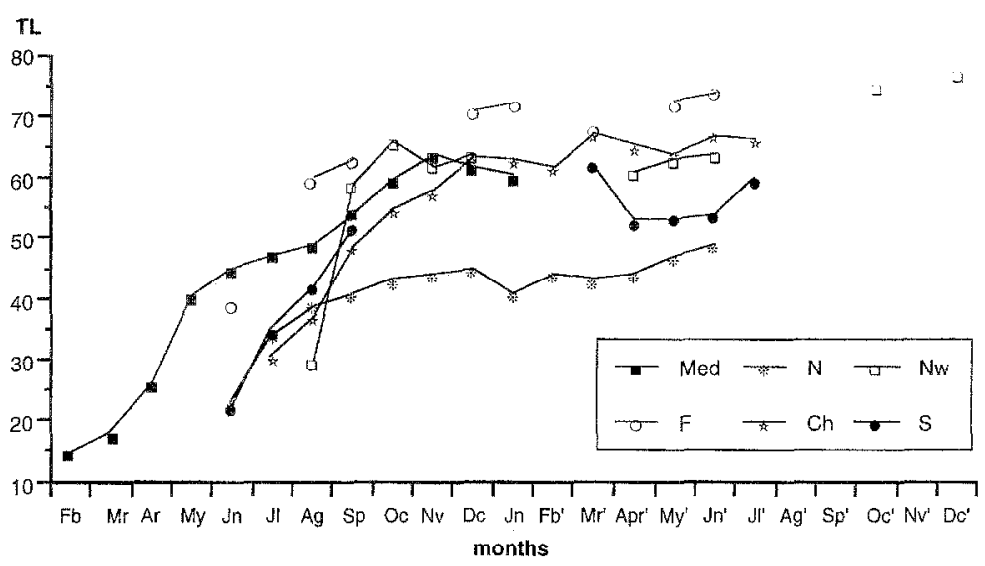

Figure 1. Linear growth curves (TL in mm) of P. minutus from different areas; Med: Mauguio lagoon, Languedoc, South of France [12]; F: Penpoul, Brittany, France [91]; N: Grevelingen lake, Nedherlands [23]; Clı: Plymouth, South of England [60]; Nw: Hvervenbutka, Oslofjord, Norway [50]; S: Gullmarfjord, Sweden [91].

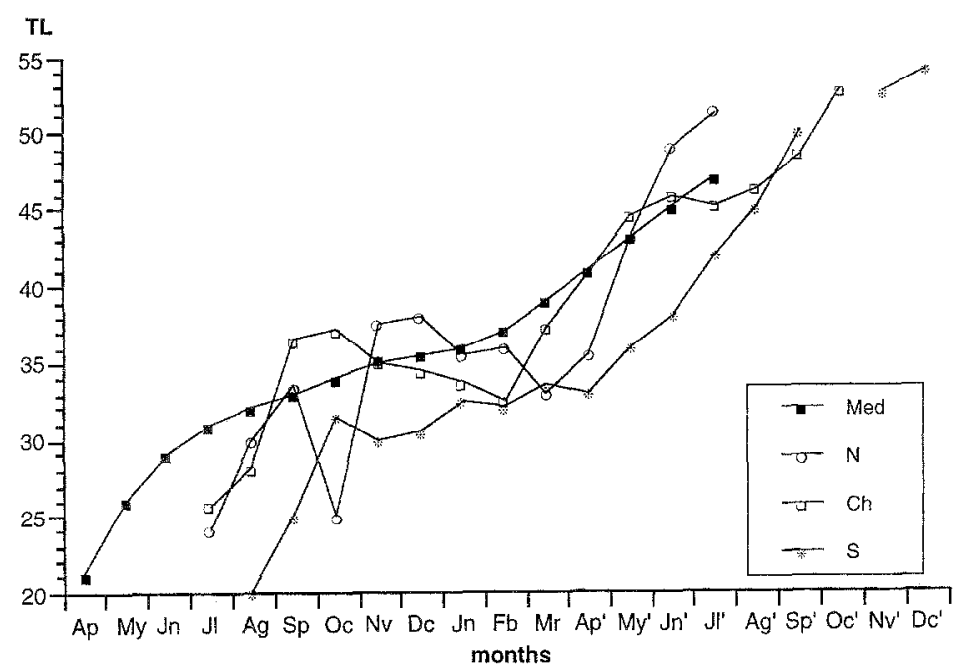

Figure 2. Linear growth curves ( $\mathrm{IL}$ in $\mathrm{mm}$ ) of $P$. microps from different areas; Med: Mauguio lagoon, Languedoc, South of France [9]; N: Grevelingen lake, Netherlands [23]; Ch: Teign Estuary, South of England [34]; S: Ythan Estuary, Scotland [45].

For the multiannual (three to five years) $G$. niger, growth is also different in the Atlantic and the Mediterranean (figures 3,4 ), that on the Norwegian coasts being a particular case. Growth rate (figure 3) in the Mediterranean populations (Mauguio lagoon, Adriatic) is, during the first year, clearly higher than of Atlantic populations. Afterwards, it decreases strongly in the Mediterranean but regulates itself in the Allantic. After the third year, differences in size are less evident, but the final performances (tables $I, I I$ ) arc better in the north-western Mediterranean $(136 \mathrm{~mm})$ than in the Atlantic $(130 \mathrm{~mm})$. The G. niger population of Norway presents the lowest growth rate. It decreases progressively and noticeably only to reach the relatively low maximum size of $96 \mathrm{~mm}$ (figure 3) with an asymptotic limit of $110.1 \mathrm{~mm}$. Therefore, the Mediterranean G. niger possess from the start of their life cycle an advantage in size over the Atlantic populations, an advantage that persists, although the growth rate slows down after the first year. The difference in growth rate favouring the males (figure 4) of the Mediterranean populations (Gulf of Lions, Adriatic) must also exist in the Atlantic as Vaas et al. [96] noticed, in $63 \%$ of the cases, a similar difference between the sexes. In Norway, Nash [75] observed a more rapid growth in females than in males (according to the work of von Bertalanffy), but the males reaching a theoretical limiting size $(L \infty)$ 


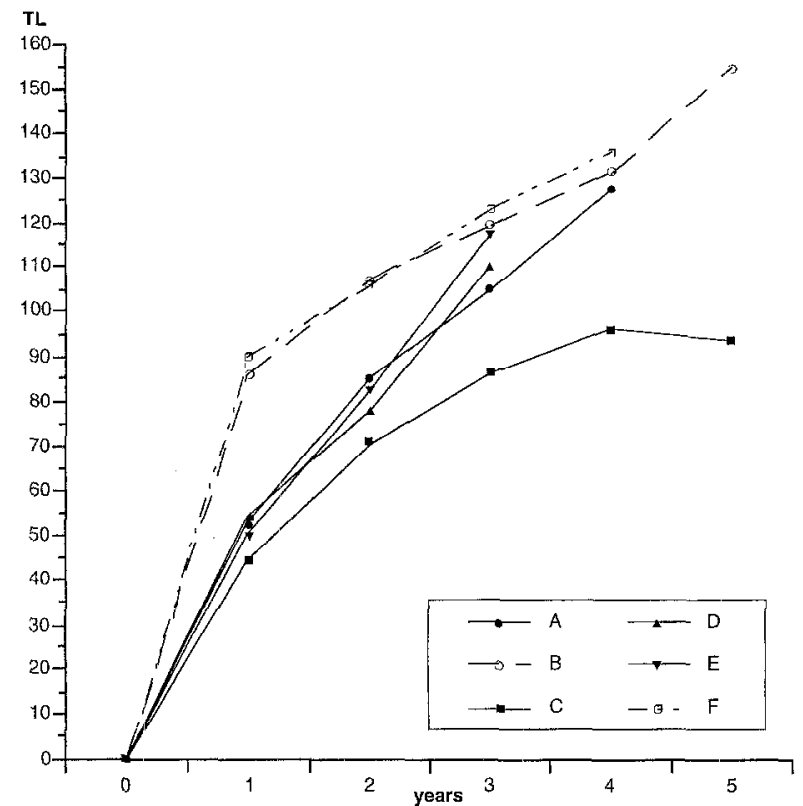

Figure 3. Linear growth (TL), and length of life in years for G. niger in various areas regardless of sex. A: Netherlands [96]; B: Adriatic [28]; C: Norway [75]; D: England [101]; E: Netherlands [23]; F: France [54].

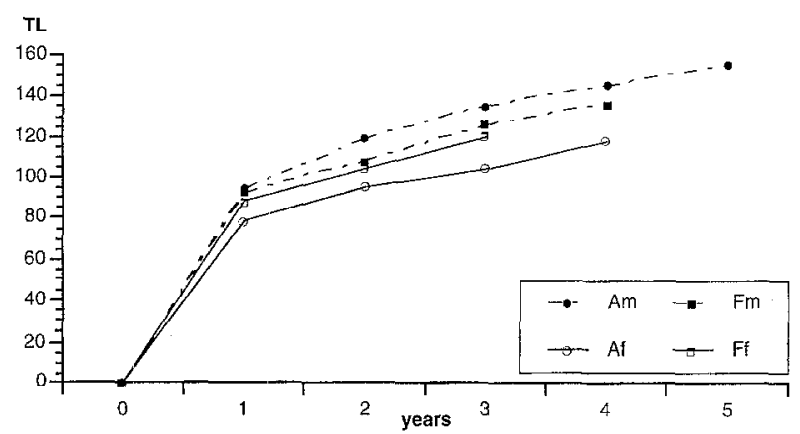

Figure 4. Growth, longevity for $G$. niger according to sex; $m$ : males; f: females; A: in the Adriatic [28]; F: in the Gulf of Lions, France [54]

greater than that of females. A differential mortality hypothesis cannot be overlooked, as females must die before males. Observed differences in growth, and mainly in sizes reached during the first year, could be related to the timing of the spawning period and to the age at first sexual maturity, both occurring later in the Atlantic than in the Mediterranean. Theoretically, the good growth and the largest sizes noted in the Gulf of Lions and particularly in the Mauguio lagoon should have positive consequences on the demographic level of these populations (minimizing impact of predators, and promoting reproductive success). However, in the case of the Mauguio lagoon population, the numerical density remains relatively low compared to those described for the Adriatic and the Atlantic [75, 96].

\subsection{Demographic structure}

\section{Size and age}

Maximum sizes of $P$. minutus in the Mauguio lagoon (table I) are lower $(87 \mathrm{~mm})$ than those $(99 \mathrm{~mm})$ observed in the Atlantic (table II). The Mauguio lagoon's population differs in several points from those north of the English Channel by age and size. Contrary to what was observed in our area, there does not seem to be any dimorphism of size in favour of males. With regard to the population, during the year, a higher fluctuation in size and mass frequency distributions can be noted in Mauguio. This fluctuation, resulting from the presence of a single age class $\left(0^{+}\right)$, contrasts with the relative stability of the Atlantic population which results from the coexistence of two or three age classes $\left(0^{+}, 1^{+}, 2^{+}\right)$during most of the year. The consequences of these structural and dynamic differences must certainly account for the sharing, during the spatial and trophic exploitation, of the environment resulting in less intra- and interspecific competition than in the Mediterranean [7, 11]. The difference in the number of generations able to coexist according to the season (one or two in Mauguio lagoon, two or three in the Atlantic) is due to an early death (twelve months on average) of the lagoon's specimens, after a single spawning at sea.

Maximum sizes of P. microps (table I) in the Mauguio lagoon are lower $(53 \mathrm{~mm})$ than those $(64 \mathrm{~mm})$ observed in the Atlantic (table II). A statural dismorphism favouring the males can also be observed only in the Mediterranean. The Mediterranean population studied has a unimodal size distribution except at the beginning of recruitment. The rapid growth of the $0^{+}$yearlings and their swift integration with the older $1^{1}$ specimens, which are dying out, could explain this relatively stable structure. In the Atlantic, the size distribution is multimodal. As for $P$. minutus, this difference is due to the existence of an additional age class in the Atlantic. The species is sufficiently long-lived and numerous to be distinguished in the size frequency distribution. Some Mauguio lagoon population specimens live more than one year, but 
Table I. Comparison of demographic variables for the three species studied in the Mauguio lagoon; TL: total length; references are: (1) Bouchereau, 1994; (2) Bouchereau et al., 1990a; (3) Bouchereau et al., 1989a; (4) Bouchereau et al., 1989b; (5) Bouchereau et al., 1990b; (6) Bouchereau et al., 1989c; (7) Bouchereau et al., 1993a; (8) Bouchereau et al., 1990c; (9) Bouchereau et al., 1991; (10) Joyeux et al., 1991a; (11) Joyeux et al., 1991b; (12) Joyeux et al., 1992; (13) Quignard et al., 1989.

\begin{tabular}{|c|c|c|c|}
\hline Variables & P. minutus & P. microps & G. Niger \\
\hline Maximum size ( $\mathrm{TL}$ in $\mathrm{mm}$ ) & $\begin{array}{l}89 \\
(5)\end{array}$ & $\begin{array}{l}53 \\
(3)\end{array}$ & $\begin{array}{l}136 \\
(10)\end{array}$ \\
\hline Life span & $\begin{array}{l}\text { annual } \\
(6)\end{array}$ & $\begin{array}{l}\text { annual } \\
\text { (3) }\end{array}$ & $\begin{array}{l}4 \text { years, } m \\
3 \text { years, } f \\
(10)\end{array}$ \\
\hline Age at first maturity & $\begin{array}{l}10 \text { months } \\
(8)\end{array}$ & $\begin{array}{l}4 \text { months } \\
\text { (7) }\end{array}$ & $\begin{array}{l}7-13 \text { months } \\
\text { (11) (12) }\end{array}$ \\
\hline Size at first maturity & - & $\begin{array}{l}27 \mathrm{~mm} \\
(7)\end{array}$ & $\begin{array}{l}43 \mathrm{~mm}, \mathrm{~m} \\
54 \mathrm{~mm}, \mathrm{f} \\
\text { (11) (12) }\end{array}$ \\
\hline Spawning perind & $\begin{array}{l}\text { Dec.-Mar } \\
(8)\end{array}$ & $\begin{array}{l}\text { Mar-Sep. } \\
\text { (4) }\end{array}$ & $\begin{array}{l}\text { Mar-Sep. } \\
\text { (11) }\end{array}$ \\
\hline Duration of spawnings & $\begin{array}{l}4-5 \text { months } \\
\text { (8) }\end{array}$ & $\begin{array}{l}\text { 6-7 months } \\
\text { (4) }\end{array}$ & $\begin{array}{l}7 \text { months } \\
\text { (11) }\end{array}$ \\
\hline Number of spawnings & $\begin{array}{l}12 \\
(1)\end{array}$ & $\begin{array}{l}11 \\
(1)(7)\end{array}$ & $\begin{array}{l}12-18 \\
(11)\end{array}$ \\
\hline Relative & $883-1575$ & $766-2333$ & $1372-1754$ \\
\hline Fecundity & $\begin{array}{l}47 \leq \mathrm{TL} \leq 73 \\
(8)\end{array}$ & $\begin{array}{l}31 \leq \mathrm{TL} \leq 46 \\
\text { (4) }\end{array}$ & $\begin{array}{l}122 \leq \mathrm{TL} \leq 54 \\
\text { (11) }\end{array}$ \\
\hline Migration/Sedentariness & $\begin{array}{l}\text { reproductive } \\
\text { (6) }\end{array}$ & $\begin{array}{l}\text { sedentary } \\
\text { (5) }\end{array}$ & $\begin{array}{l}\text { erratic } \\
\text { (1) }\end{array}$ \\
\hline Nestable substratum & $\begin{array}{l}\text { abundant } \\
\text { (sea) } \\
(9)\end{array}$ & $\begin{array}{l}\text { abundant } \\
\text { (lagoon) } \\
(9)\end{array}$ & $\begin{array}{l}\text { rare } \\
\text { (lagoon }+ \text { sea) } \\
\text { (1) }\end{array}$ \\
\hline $\begin{array}{l}\text { Sex ratio } \\
\text { (during reproductive activity) }\end{array}$ & - & $1 \mathrm{~m}: 3 \mathrm{f}$ & $\begin{array}{l}1,5 \mathrm{~m}: 1 \mathrm{f} \\
(10)(12)\end{array}$ \\
\hline Population structure & $\begin{array}{l}\text { unimodal } \\
\text { (dynamic) } \\
(6)\end{array}$ & $\begin{array}{l}\text { unimodal } \\
\text { (static) } \\
(3)\end{array}$ & $\begin{array}{l}\text { polymodal } \\
\text { (static) } \\
(10)\end{array}$ \\
\hline Numeric density & $\begin{array}{l}\text { high } \\
\text { (2) (13) }\end{array}$ & $\begin{array}{l}\text { high } \\
\text { (2) (13) }\end{array}$ & $\begin{array}{l}\text { low } \\
(2)(13)\end{array}$ \\
\hline
\end{tabular}

because of their small number, the population can be considered from the functional point of view as annual.

The extreme sizes (tables I, II) of G. niger living in the Mauguio lagoon $(136 \mathrm{~mm})$, greater than those observed in Atlantic population $(130 \mathrm{~mm}$, not taking into account data obtained from reared stock by Wheeler [105]), do not reach the sizes observed in the Adriatic $(165 \mathrm{~mm})$. Moreover, a dimorphism favouring males seems more noticeable in the Atlantic. Its size-frequency distribution is multimodal in most areas with three to five age classes according to sex (table 11, figure 3). In the Atlantic (England), $98 \%$ of the population is represented by the first two age classes, $0^{+}$and $1^{+}$, while three classes are represented in Mauguio lagoon. There the male life cycle is longer than that of the females. Although this male longevity is less important, the situation is shared with that of the Adriatic and seems to be an Adriatic-Mediterranean characteristic. The maximum age reached by specimens of $G$. niger from the Mauguio lagoon is within the longevity limits observed over the biogeographical distribution area (table II, figure 3). Indeed, if G. niger longevity is similar (four to five years) on the Norwegian and Adriatic coasts (figure 3), the life span seems to be shorter (three to four years) in the Atlantic lagoons and estuaries, and in the Mediterranean, mainly for females (figure 4). Generally the growth curves of Dutch and English specimens (figure 3), show a higher growth rate after the first year, while not reaching asymptotic length, possibly indicating a potential longevity greater than those observed by Vaas et al. [96], Vesey and Langford [101], and Doornbos and Twisk [23]. Also, the maximal size of $170 \mathrm{~mm}$ given for the Atlantic (aquarium raised? 
Table II. Summary of main demographic variables of the species studied for the Atlantic area; authors are mentioned under following numbers between brackets: (1) Bouchereau et al., 1989c; (2) Claridge et al., 1985; (3) Doornbos and Twisk, 1987; (4) Duncker and Ladiges, 1960; (5) Fvans and Tallmark, 1985; (6) Fonds, 1970; (7) Fonds, 1971; (8) Fonds, 1973; (9) Fouda and Miller, 1981; (10) Guitel, 1892; (11) Hamerlynck et al., 1986; (12) Hamerlynck and Cattrijsse, 1994; (13) Healey, 1971a; (14) Healey, 1971b; (15) Healey, 1972; (16) Hesthagen, 1975; (17) Hesthagen, 1977; (18) Jones and Miller, 1966; (19) Joyeux et al., 1991b; (20) King et al., 1980; (21) Kunz, 1969; (22) Lawacz, 1965; (23) Lee, 1974; (24) Le Menn, 1974; (25) Magnhagen, 1986; (26) Miller, 1964; (27) Miller, 1975; (28) Miller, 1979; (29) Miller, 1984; (30) Nash, 1984; (31) Shann, 1910; (32) Swedmark, 1957; (33) Swedmark, 1958; (34) Vaas et al., 1975; (35) Van der Gaag, 1979; (36) Vesey and Langford, 1985 ; (37) Wheeler, $1969 ;$ ( ) present work.

\begin{tabular}{|c|c|c|c|}
\hline Variables & P. minutus & P. microps & G. Niger \\
\hline Maximum size (TL) & $\begin{array}{l}95-99 \mathrm{~mm} \\
(8,32)\end{array}$ & $\begin{array}{l}64 \mathrm{~mm} \\
(18)\end{array}$ & $\begin{array}{l}130 \mathrm{~mm} \\
(34)\end{array}$ \\
\hline Life span & $\begin{array}{l}20-23 \text { months } \\
(2,7,8,13,16,17,31,32)\end{array}$ & $\begin{array}{l}\text { 19-23 months ( } 27 \text { Teign }) \\
(5,9,15,18,27,29)\end{array}$ & $4-5$ years $(3,30,34,36)$ \\
\hline Size structure of the population & $\begin{array}{l}\text { bimodal } \\
(2,7,8,13,14,16,32,33)\end{array}$ & $\begin{array}{l}\text { bimodal } \\
(9,27,35)\end{array}$ & $\begin{array}{l}\text { polymodal (34) } \\
\text { England: bimodal (36) }\end{array}$ \\
\hline Growth period & $\begin{array}{l}\text { reduced in winter } \\
(3,8,13,16,31,32,33)\end{array}$ & $\begin{array}{l}\text { reduced in winter }(15,26) \\
\text { and summer }(26)\end{array}$ & $\begin{array}{l}\text { May-Sept. remaining relatively low } \\
\text { every year }(34.36)\end{array}$ \\
\hline First maturity: age & $\begin{array}{l}12 \text { months } \\
(2,3,8,14,23)\end{array}$ & $\begin{array}{l}12 \text { months } \\
(15,26,37)\end{array}$ & $\begin{array}{l}\text { males: } 2 \text { years } \\
\text { females: } 3 \text { years }(19)\end{array}$ \\
\hline First maturity: size & $\begin{array}{l}43 \mathrm{~mm} \\
(23)\end{array}$ & $\begin{array}{l}26 \mathrm{~mm}(22) \\
\mathrm{m} 29 \mathrm{~mm}, \mathrm{f} 31 \mathrm{~mm}, \mathrm{~S}\end{array}$ & $\begin{array}{l}50 \mathrm{~mm}, \text { England (36) } \\
90 \mathrm{~mm}(26), \text { Ireland (20) }\end{array}$ \\
\hline Spawning period & $\begin{array}{l}\text { March/April/May to July } \\
(2,11,12,13,14)\end{array}$ & $\begin{array}{l}\text { April/May to Aug/Sept. } \\
(2,15,18,22,26,27)\end{array}$ & $\begin{array}{l}\text { April/May to July/Aug. } \\
(24,30,34,36)\end{array}$ \\
\hline Number of spawnings & $\begin{array}{l}2 \text { to } 12 \\
(6,8,14)\end{array}$ & $\begin{array}{l}6 \text { to } 9 \\
(10,26,28,29)\end{array}$ & $\begin{array}{l}1 \text { to } 2 \\
(24,34)\end{array}$ \\
\hline $\begin{array}{l}\text { Absolute fecundity } \\
\text { per spawning act }\end{array}$ & $\begin{array}{l}5850(\text { TL: } 90 \mathrm{~mm}) \\
(2,14,23)\end{array}$ & $\begin{array}{l}3400(\mathrm{TL}: 46 \mathrm{~mm}) \\
(15,28)\end{array}$ & $\begin{array}{l}2000 \\
(36)\end{array}$ \\
\hline Relative fecundity & $\begin{array}{l}428-835(62 \leq \mathrm{TL} \leq 78) \\
397-772(82 \leq \mathrm{TL} \leq 90) \\
(14,23)\end{array}$ & $\begin{array}{l}1315-1599 \\
(35 \leq \mathrm{TL} \leq 57) \\
(23,28)\end{array}$ & $\begin{array}{l}118-583 \\
(100 \leq \mathrm{TL} \leq 44) \\
(23,36)\end{array}$ \\
\hline Migration & $\begin{array}{l}\text { genesic and thermic } \\
(7,8,16,17,31,33)\end{array}$ & $\begin{array}{l}\text { thermic } \\
(9,15,18,21)\end{array}$ & $\begin{array}{l}\text { thermo-genesic? } \\
\text { (30) }\end{array}$ \\
\hline Sex ratio: $\mathrm{m} / \mathrm{f}$ & $\begin{array}{l}1: 1 \\
(7,8,13,14,16,33)\end{array}$ & $\begin{array}{l}1: 1 \\
(4,25,29)\end{array}$ & $\begin{array}{l}0,97-1,04: 1(30,34) \\
0,5: 1(36)\end{array}$ \\
\hline Maximum number of age classes & $\begin{array}{l}2 \text { to } 3 \\
\text { (1) }\end{array}$ & $\begin{array}{l}3 \\
()\end{array}$ & $\begin{array}{l}6 \\
()\end{array}$ \\
\hline
\end{tabular}

[105]) confirms this hypothesis. The maximum age must surely depend on the reproductive activity (tables III to $V$ ) of the species (date, duration), on first sexual maturity (size, age), and the number of spawnings (table $\mathrm{V}$ ) completed during the adult life $[55,57]$.

\section{Sex ratio}

$P$. minutus has a balanced sex-ratio (male/female, $1: 1$ ) in Mauguio lagoon [9] and indeed throughout its distribution area $[32,33,43,44,49,91]$. This is probably because of effect of "good" marine conditions of the environment where spawning takes place (see $\S$ migrations). However, the sex ratio analysis during the year revealed a distinctive feature in the Mauguio lagoon population. We observed a higher rate of females caught with the "capechade" (local fixed-nets) from the beginning of migration, probably because of the wider abdomen with ovary development, and we observed a sex-ratio variation with size related to the growth differences existing in this lagoon between males and females. 
The P. microps situation in Mauguio lagoon is different. All year round, an instability in the sex-ratio, favouring females $(0.53: 1)$, is observed [12] although it is even greater during spawning $(0.28: 1)$ and this situation may not be found all over the distribution area of the species. In the Atlantic, it is mentioned only for the North Sea and on Swcdish coasts. Such a sex ratio in those areas, and particularly in the Mauguio lagoon, contributes to the reproductive success of the species, enabling males to ensure the full usage of the nest and to optimize the number of broods, if for any reason an acceleration occurs in the turnover of egg batches. As the spawning takes place in the lagoon or in the estuaries, factors and occurrences leading to such an accelaration are various: destruction of nest by predators or a hydroclimatic crisis, decrease in the development time due to a temperature rise, etc..

The $G$. niger sex ratio is variable (0.5:1 to $2: 1)$ according to the area studied $[28,75,96,101]$. Male prevalence is more pronounced in the Mediterranean (1.39:1 or 1.92:1) than in the Atlantic, where it is sometimes is not evident (0.97:1 to 1.04:1). This prevalence of males in the Mauguio lagoon [54] and in the Gulf of Lions must be of an adaptive value, enabling G. niger to occupy a maximum of rare spawning sites in biotopes which lack such places (sandy coasts or muddy lagoons). However, for such biased sex ratios to evolve through natural selection, some spatial structure or some degree of homogamy would be necessary. The increase in the number of males in relation to their size or age is important for the Mauguio lagoon's $G$. niger. It results from important differences in growth and mortality related to the great investment of females in reproduction.

\subsection{Migration}

There are obvious differences in the migratory behaviour of $P$. minutus and P. microps in the Mediterranean and in the Atlantic. In the Gulf of Lions, the migratory cycle of $P$. minutus, between lagoon and sea, is unique [15] and can be called ontogenic as it perfectly coincides with the fish life cycle. On the other hand, the Atlantic specimens from a single population can undertake several migrations from the shore out to sea during the same year, sometimes doing this for two consecutive years. Thus, various authors were able to describe this annual winterly thermal migration $[43,49,73,91]$, which cannot be mistaken for spring and summer genesic migrations [18, 20, 32,33 ]. A yearly thermal summer migration can also take place $[50,51]$. The factors affecting the Gulf of Lions sea/lagoon migration seem more complex than those of the Atlantic. In this environment, not only the hydroclimatic conditions are often unfavourable at spawning time (in winter) in the Mauguio lagoon, but also for nesting, due to an important lack of potential nest sites (large shells of Lamellibranch).

In the Atlantic, $P$. microps can migrate for spawning, or outside the breeding season to avoid low salinity $[18,58$, $65,67]$ or low (figure 5) temperatures $[18,34,45,78]$. On the other hand, in the Mauguio lagoon despite an unstable environment, $P$. microps is sedentary. Around our area, $P$. minutus and $P$. microps populations are less mobile than in the Atlantic or the North of Brittany. G. niger is probably sedentary in Mauguio lagoon, as in most of the Gulf of Lions. However, it has migratory potential in the Atlantic; and in the Adriatic, "gatherings" of spawners were observed. There is no typical migrational pattern which could be applied to its entire distribution area. Populations respond according to the local circumstances and with a great plasticity to the environmental conditions which enables them to adapt to various sites and to occupy them successfully.

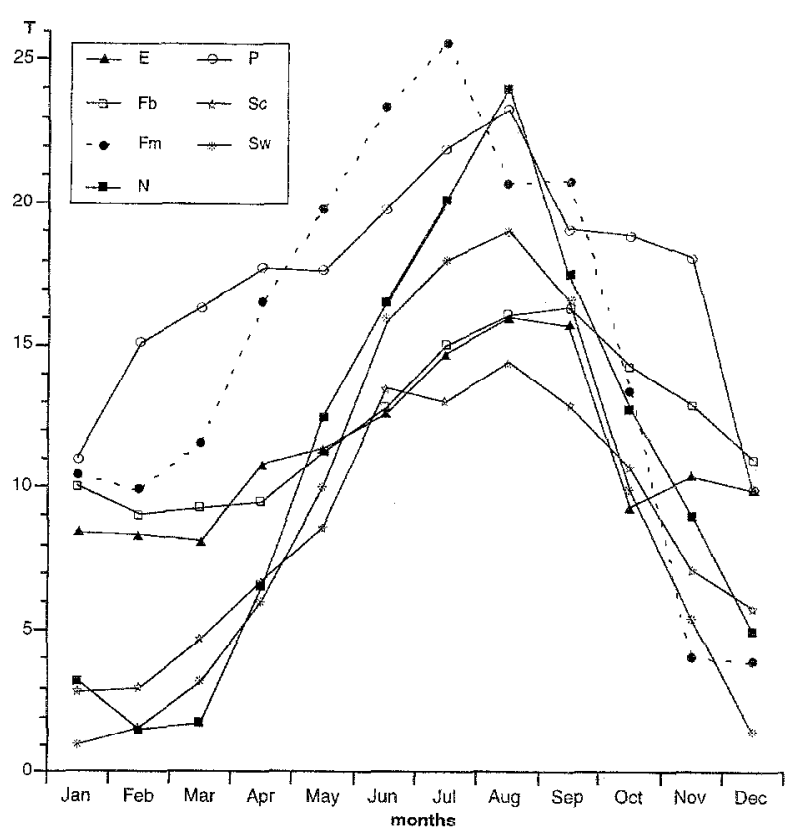

Figure 5. Monthly temperatures $\left(\mathrm{T}\right.$ in ${ }^{\circ} \mathrm{C}$ ), in the distribution area of $P$. minutus, $P$. microps and $G$. niger; F. Plymouth, South of England [60]; Fb: Penpoul, Brittany, France [91]; Fm: Mauguio lagoon, France [8, 9]; N: Hvervenbutka, Oslofjord, Norway [50]; P: Tagus Estuary, Portugal [72]; Sc: Ythan Estuary, Scotland [43]; Sw: Gullmarfjord, Sweden [91]. 


\subsection{Sexuality, reproduction}

The $P$. minutus population remaining in the Mauguio lagoon and the Gulf of Lions spawns during only one season, as opposed to two in the Atlantic. The spawning of P. minutus in the Gulf of Lions takes place in winter and finishes before spawning starts in the Atlantic during spring and summer (table III). This precocity in the Meditcrancan (Mauguio lagoon) cnables all $P$. minutus specimens to reach, before winter, their size of first sexual maturity and to take part in the spawning during their first year. The positioning of breeding date in relation to seasons means that the Mauguio lagoon population migrates only once per year (in winter), in contrast with the two separate migrations (one thermal and one reproductive) undertaken by the Atlantic populations that spawn rather closer to summer. This reduction of movement in the Mediterranean (Mauguio lagoon), limiting energy expenditure, could reduce mortality in age classes caused by movements of individuals (because of one less migration); losses could be compensated in the Atlantic by a larger post-spawning survival. The shortage thus created in larval production could then be compensated for by their greater longevity enabling them to participate in a second spawning ( 1 to $2 \%$ from the population of survivors). In the Mediterranean (Mauguio lagoon), on the other hand, mortality is complete after spawning (the specimens involved being completely eliminated).

For $P$. microps, spawning occurs at least twice per individual, irrespective of geographical location. However, depending on the area, there are fundamental differences in the occurrence of the breeding periods during the life of this fish. Spawning time is determined by the longevity of the specimen. In fact, in a given population and a given age class (cohort), whether in the Mediterranean or the Atlantic, two groups of spawners can be observed, characterized as much by their age as by their number. One group, which could be called the principal (major) one, present in both areas, is composed of many one-year-old specimens spawning during the whole period of reproduction. A secondary group (minor), composed in the Mediterranean (Mauguio lagoon) of individuals aged four to five months $\left(0^{+}\right)$, represents $13.8 \%$ of the population and spawns only during a few weeks towards the end of the period [13]. However, in the Atlantic, this secondary group is conoposed of individuals aged from 20 to 24 months and represents 5 to $8 \%$ of the population, spawning at the start of the breeding season before dying $[34,45,53,67,69]$.
In both cases, one can wonder if the secondary groups (minor groups) must be considered not only from the individual but also mainly from the populational level, in relation to the improvement of reproductive success. The difference between populations from both areas lies in its position in time: at the start of the life cycle for the Mediterranean and at the end of it for the Atlantic. It must be noted that the tactic used by $P$. microps is not exceptional in the Mediterranean as it was also observed in the Syngnathus abaster of Mauguio lagoon [91].

The precocity of the first sexual maturity in the Mediterranean (Mauguio lagoon) could be a compensating response to the high death rate affecting adults. This occurs in this area because the hydroclimatic and trophic conditions induce a sufficiently early spawning period for specimens reaching an age and size permitting gonad maturity and allowing reproduction to take place before the first winter following their birth. In the Atlantic, the late spawning does not permit attainment of the minimum age compatible for first maturity before winter. These results are in agreement with the predictive model for age/size at first maturity $\left(\mathrm{n}^{\circ} 4\right)$ proposed by Stearns and Crandall [89] in which first maturity is advanced when the growth rate decreases following an increase in the adult death rate.

The fecundity rate gained by the spawning of the $0^{+}$in the Mediterranean and that of the $2^{+}$in the Atlantic may be comparable. The low fecundity of the small Mediterranean $0^{+}$individuals compared to that of the Atlantic $2^{+}$could be compensated for by their higher number and the hetter quality of their gametes. In other words, the population living in Mauguio lagoon has a strategy based on their number (table $I$ ) and in the Atlantic based on the size of their begetters (table $V$ ). If the pairing of the spawning of $2^{+}$from the start of the reproduction period represents an advantage in the Atlantic ensuring larger post larvae in winter, the late spawning of $0^{+}$in the Mediterranean is not a handicap (unless it causes a high death rate in these spawners). The winter season comes later in the Mediterranean area, enabling young to grow sufficiently before the onset of bad hydroclimatic conditions. Also, the recruitment of new spawners $0^{+}$during summer is a compensating element for the mortality generated by the various crises (anoxia, dystrophy) frequent in the lagoons at this time of the year.

Between the G. niger populations, the parameters of reproduction (tables $I I I, I V, V$ ) diverge according to the fecundity per spawning act and the number of batches, and converge where length and number of spawning periods are concerned. With regard to reproductive investment, the balance at the end of the life cycle is greater in 
Table III. Maximum sizes (TL) and breeding periods (dates and durations) of gobies (males, $\mathrm{m}$, and females, $\mathrm{t}$ ) $P$. minutus, $P$. microps, Gobius niger, in different areas; start and end: spawning periods limits; peak: maximum intensity of spawning: months in arabic numerals; length in numbers of months; maximal total length, LTmax, in mm.

\begin{tabular}{|c|c|c|c|c|c|c|}
\hline \multirow{2}{*}{$\frac{\text { Localities }}{P . \text { minutus }}$} & \multicolumn{2}{|c|}{ begining peak } & \multirow[t]{2}{*}{ end } & \multirow[t]{2}{*}{ duration } & \multirow[t]{2}{*}{$\max T L$} & \multirow{2}{*}{ authors } \\
\hline & & & & & & \\
\hline Oslofjord-Norway & 4 & $4-6$ & 7 & 4 & 73 & Hesthagen, 1977 \\
\hline \multicolumn{7}{|l|}{ Hvervenbutka } \\
\hline Faroes-Iceland & & & & & 76 & Täning, 1940 \\
\hline Gullmarsfjd-Sweden, Ouest Sweden & 3 & & 7 & 5 & 83 & Swedmark, 1958; Evans \& Tallmark, 1984 \\
\hline St Andrews & & & & & 79 & Shann, 1910 \\
\hline Ask $\varnothing$, North Baltic & 5 & $6-7$ & 7 & 3 & & Wahlberg, 1969; Nellbring, 1986 \\
\hline Baltic & 4 & & 7 & 4 & & Heincke, 1880 \\
\hline North Sea & 3 & & & & & Duncker, 1928, in Lawacz, 1965 \\
\hline Gdansk Bay & 6 & & 10 & 5 & & Mankowski, 1947 \\
\hline Puck Bay, Poland & 4 & & 8 & 4.5 & 74 & Lawacz, 1965 \\
\hline Helder, Germany & & & & & 81 & Hass, 1937 \\
\hline Ythan est., Scotland, Aberdeen & 2 & & 6 & 5 & 90 & Healey, 1971a,b \\
\hline Waddensee & 4 & & 8 & 5 & 95 & Fonds, 1973 \\
\hline Grevelingen Lake (Netherlands) & & & & & 80 & Doornbos \& Twisk, 1987 \\
\hline Plymouth, South (England) & 2 & & 5 & 4 & $87 m-82 f$ & Lee, 1974 \\
\hline Tage, Purtugal & 5 & & & & 99 & Mureira el al., 1991 \\
\hline Penpoul-Britan & 3 & & 7 & 5 & 95 & Swedmark, 1958 \\
\hline languedoc, G. of Lions, France & 12 & $1-3$ & $3 / 4$ & $4 / 5$ & $87 \mathrm{~m}-81 \mathrm{f}$ & Bouchereau et al., 1989c, 1990c \\
\hline Varna, Black Sea, Bulgaria & $2 / 3$ & & 7 & 5 & & Georghiev, 1966 \\
\hline \multicolumn{7}{|l|}{ P. microps } \\
\hline Ora Estuary, S-E. Norway & $5 / 6$ & $6-8$ & 9 & 4.5 & & Pethon, 1975 \\
\hline Gullmarsfjord, O. Sweden & 4 & & $7 / 8$ & 4.5 & & Evans \& Tallmark, 1984 \\
\hline Ask $\emptyset$, N. Baltic & 6 & 7 & $8 / 9$ & 3.5 & & Wahlberg, 1969; Nellbring, 1986 \\
\hline Puck Bay, Poland & 4 & & 8 & 5 & 52 & Lawacz, 1965 \\
\hline Niva Bay, Danmark & 5 & & 8 & 4 & & Muus, 1967 \\
\hline Kiel Bay, Germany & 5 & & 8 & 4 & & Hass, 1936 \\
\hline Ythan Estuary, Scotland & 5 & & $7 / 8$ & 3.5 & 53 & Healey, 1972 \\
\hline Grevelingen Lake, Netherlands & & & & & 51 & Doornbos \& Twisk, 1987 \\
\hline \multicolumn{7}{|l|}{ Severn Estuary } \\
\hline Morecambe Bay & 4 & $5-6 / 7$ & $8 / 9$ & 5.5 & 64 & Jones \& Miller, 1966 \\
\hline Teign Estuary & 4 & & $8 / 9$ & 5.5 & $51 \mathrm{~m}-45 \mathrm{f}$ & Shih, 1979; Fouda \& Miller, 1981 \\
\hline Channel England & & & & & $52 \mathrm{stL}$ & Claridge et al., 1985 \\
\hline Tage Estuary, Portugal & & & & & $\begin{array}{l}50 \mathrm{~m} \mathrm{stL} \\
46 \mathrm{fstL}\end{array}$ & Moreira et al., 1991 \\
\hline Mauguio-Languedoc, g. of Lions, France & 3 & 4 & $8 / 9$ & $6 / 7$ & 53 & Bouchereau et al., 1989a,b \\
\hline Messine, Sicile & 4 & & 6 & 3 & & Sparta, 1936 \\
\hline \multicolumn{7}{|l|}{ G. niger } \\
\hline Oslofjord, Norway & 4 & $5-6$ & 7 & 4 & $129 \mathrm{~m}, 127 \mathrm{f}$ & Nash, 1984 \\
\hline Irelande & 4 & - & 8 & 5 & & Fives, 1970 \\
\hline Veere Lake & & & & & 130 & Vaas et al., 1975 \\
\hline Channel-England & 4 & $4-5$ & $5(9)$ & $2(6)$ & $12 G f$ & Vesey \& Langford, 1985 \\
\hline Mauguio-Languedoc, g. of Lions, France & 3 & $4-8$ & 9 & $6-7$ & $136 \mathrm{~m}, 124 \mathrm{f}$ & Joyeux et al., 1991a,b. \\
\hline Tyrhénian Sea & 3 & & 5 & & & Padoa, 1953; Ballard, 1969 \\
\hline Adriatic Sea & 4 & & 8 & 5 & 165 & Fabi \& Froglia, 1984 \\
\hline
\end{tabular}

the Gulf of Lions when compared with the Atlantic. The fecundity per spawning act and the number of spawnings of $G$. niger for each reproductive period along within its reproductive life is greater in Mauguio lagoon than in the Adriatic or the Atlantic (table $I V$ ). Nevcrthcless, the advantage of such a situation is not clearly shown in the 
Table IV. Extremes or mean*, absolute $\mathrm{F}$ and relative RF goby fecundities, $P$. minutus, $P$. microps, $G$. niger, in different localities, and number $\mathrm{N}$ of estimated spawnings per season or per month according to author(s).

\begin{tabular}{|c|c|c|c|c|c|c|}
\hline Localities & $\min F$ & $\max F$ & $\operatorname{minRF}$ & $\max F R$ & $\mathbf{N}$ & authors \\
\hline \multicolumn{7}{|l|}{ P. minutus } \\
\hline Ythan Estuary, Scotland & 2394 & 5850 & 428 & 835 & $>1$ & Healey, 1971b \\
\hline $\begin{array}{l}\text { Severn Estuary, } \\
\text { England }\end{array}$ & 5231 & 5603 & & & & $\begin{array}{l}\text { Claridge et al., } 1985 \\
\text { ( } \mathrm{n}=2 \text { individus) }\end{array}$ \\
\hline Netherlands & & & & & $1-2 /$ mois & Fonds, 1973 \\
\hline Teign Est-Channel, England & 712 & 5389 & & $* 1462$ & 12 & Lee, 1974 \\
\hline Penpoul, Brittany & & & & & $>1$ & Swedmark, 1958 \\
\hline \multicolumn{7}{|l|}{ France } \\
\hline Gulf of Lions, Lang., France & 998 & 5100 & 883 & 1575 & 12 & Bouchereau et al., 1990b \\
\hline \multicolumn{7}{|l|}{ P. microps } \\
\hline Ythan estuary & 564 & 2962 & 1315 & 1599 & & Healey, 1972 \\
\hline Scottland, England & $35 \mathrm{~mm}$ & $57 \mathrm{~mm}$ & & $* 2364$ & $2-3 /$ month & Lee, 1974; Miller, 1979 \\
\hline Brittany, France & & & & & $5 /$ month & Guitel, 1982 \\
\hline Canet, Rous., Fr. & 870 & 2100 & & & & Herve, 1978 \\
\hline Mauguio, Lang. & 460 & 2030 & 760 & 2340 & 11 & Boucliereau el al., 1989a \\
\hline France & $31 \mathrm{~mm}$ & $46 \mathrm{~mm}$ & & & & \\
\hline \multicolumn{7}{|l|}{ G. niger } \\
\hline Veerse Meer & & & & & 1 to 2 & Le Menn, 1974 \\
\hline Netherlands & & & & & & Vaas et al., 1975 \\
\hline Channel & & & & $* 536$ & & Lee, 1974; Miller, 1984 \\
\hline Channel & 700 & 2000 & 118 & 583 & & Vesey \& Langford, 1985 \\
\hline \multicolumn{7}{|l|}{ South England } \\
\hline Mauguio, Lang., France & 3319 & 37625 & 972 & 3882 & $12-18$ & Joyeux et al., 1991 b \\
\hline Adriatic Sca & & & & & 1 & Fabi \& Gianctti (1985) \\
\hline
\end{tabular}

Table V. Comparison of Mediterranean species with Atlantic populations with reference to certain reproductive parameters.

\begin{tabular}{llll}
\hline Reproduction & P. minutus & P. microps & G. niger \\
\hline Sexual maturity: age & greater & $0.5 / 1$ & $1 / 2$ to 3 \\
Size & greater & smaller & greater \\
Duration of season & equal & greater & equal or greater \\
Number of seasons & $1 / 2$ & $2 / 2$ & equal or greater \\
\hline Instantaneous absolute Fecundity & equal & smaller & greater \\
Spawning Frequency & equal & greater & greater \\
\hline
\end{tabular}

Mauguio lagoon or the Gulf of Lions. Indeed, this demographic population level, as mentioned above, is relatively low compared to that described for the Adriatic and the Atlantic, where these fishes are captured on a larger scale. A scarcity of nesting sites (sea grass beds, rocks) in the Gulf of Lions and the Maugio lagoon could be one of the factors explaining the relative failure of the reproductive effort within the Mediterranean population.

\section{CONCLUSION}

This work on three goby species, P. minutus, P. microps and $G$. niger, living over a broad geographical range, has enabled us to study thoroughly several of their bioecological characteristics and to clarify some aspects of the knowledge of their populations. This study confirms, on the whole, the great adaptability of these gobies, which endows them with the potential capacity to successfully occupy varying biotopes such as lagoons, coastal areas, and the estuaries of the Atlantic and the Mediterranean.

The observed differences concerning each of the life cycles, encountered according to their geographical location, have various explanations. One is due to the latitude of the Mediterranean area (Gulf of Lions), where day length and temperature variations are less nuticeable than at the northern limits of the three species' distributions. 
The hydroclimate of this area generates, in the populations studied, a shifting and lengthening of spawning and growth times in comparison with the Allantic. Other differences derive from the general characteristics of the shallow nature and high trophic wealth of the lagoons, likely to attract inshore species such as $P$. minutus, and from the unstable hydroclimatic environment found in the Mauguio lagoon. The latter entails a greater tolerance from the sedentary species such as $P$. microps and $G$. niger. The Mauguio lagoon's local biotopic configuration is also responsible for other differences.

It should be pointed out that further studies of those structured populations are required to interpret the different values observed for the sex ratio and to justify and support a defined concept (selection group in traits, sexual selection) in the evolution of breeding systems.

Results on goby life history traits found throughout their distribution area were obtained with different methods (trawl net, fixed net, seine) and treated with different methodologies (growth, fecundities, nests, culture in aquarium). For these reasons, it is sometimes difficult to make comparisons and test with statistical significance when differences are observed. In the meantime, on the basis of all the observations and comparisons made between the different environmental conditions encountered in the Mediterranean and Atlantic, and the demographic processes of the studied populations, it can be noted that the Mediterranean populations display a "contracted" life cycle, particularly in $P$. minutus and P. microps, whereas it is rather "protracted" for those living in the Atlantic. In the Mediterranean, there is rapid growth and significant reproduction; in the Atlantic, growth and reproductive efforts are equivalent or of lesser intensity. Finally, irrespective of the geographical location of the species, and despite the high reproductive investment of $G$. niger in the Gulf of Lions, reproductive success stays very similar in all the populations.

\section{REFERENCES}

[1] Al Hassan L.A.J., Giama M., Webb C.J., Miller P.J., Phosphoglucose isomerase polynorphism in the common goby, Pomatoschistus microps (Kroyer) (Teleostei: Gobioidei) around the British Isles, J. Fish Biol. 30 (1987) 281-298.

[2] Ahnelt A, Patzner R.A., A new species of Didogobius (Teleostei: Gobiidæ) from the western Mediterranean, Cybium 19, 1 (1995) 95-102.

[3] Ballard W.W., Normal embryonic stages of Gobius niger jozo, Publ. Staz. Zool. Napoli 37 (1969) 1-17.

[4] Benharrat K.M., Recherche d'une différentiation génétique au sein des populations ichthyiques marines et lagunaires du golfe du Lion. Analyse du polymorphisme enzymatique chez Gobius niger, Blennius pavo et Engraulis encrasicholus. Thèso $3^{\text {eme }}$ cycle, Montpellier II (1983) $151 \mathrm{p}$.

[5] Benharrat K.M., Quignard J.P., Pastcur N., Les gobies noirs (Gobius niger Linné, 1758) de la côte méditerranéenne française: variation du polymorphisme enzymatique des populations lagunaires et marines, Cybium 5 (3) (1981) 29-33.

[6] Bouchereau J.L., Bioécologie et tactiques adaptatives d'occupation d'une lagune méditerranéenne (Mauguio, Languedoc, France) par trois poissons téléostéens Gobiidés: Pomatoschistus minutus (Pallas, 1770), P. microps (Krøyer, 1838), Gobius niger Linneaus, 1758. Thèse d'Etat, Université Montpellier II, (1994) France.

[7] Bouchereau J.-L., Capape C., Tomasini J.-A., Quignard J.-P., Coxistence entre deux espèces de Gobiidés en milieu lagunaire périméditerranéen. Communication au 2eme Congrès d'Okéanos, Montpellier, 22-23 avril 1993 (1993b).
[8] Bouchereau J.-L., Capape C., Joyeux J.C., Quignard J.P., Tomasini J.-A., Les débarquenents des pêches aux Cabanes de Pérols en 1989 (lagune de Mauguio). Suivi qualitatif et quantitatif. Rapport Service Maritime et de Navigation du Languedoc-Roussillon (1990a) 62 p.

[9] Bouchereau J.-L., Joyeux J.-C., Quignard J.-P., Structure de la population de Pomatoschistus microps (Krøyer, 1838), Poissons, Gobiidés, dans la lagune de Mauguio (France), Vie Milieu 39, 1 (1989a) 19-28.

[10] Bouchereau J.-L., Joyeux J.-C., Tomasini J.-A., Quignard J.-P., La reproduction de Pomatoschistus microps (Krøyer, 1838) (Gobiidés) dans la lagune de Mauguio, France, Bull. Ecol. 20, 3 (1989b) 193-202.

[11] Bouchereau J.-L., Joyeux J.-C., Tomasini J.-A., Quignard J.-P., Effets d'une crise dystrophique sur les populations lagunocôtières méditerranéennes de Pomatoschistus microps (Krøyer, 1838 ) et de $P$. minutus (Pallas, 1770), Poissons Gobiidés. Aspects du déterminisme du recrutement, Rapp. Comm. int. Mer Médit. 1990, 32, 1 (1990b) 299.

[12] Bouchereau J.-L., Quignard J.-P., Joyeux J.-C., Tomasini J.-A., La population de Pomatoschistus minutus (Pallas, 1770) de la lagune de Mauguio, France. Paramètres démographiques et croissance individuelle, Cah. Biol. mar. 30 (1989c) 487-514.

[13] Bouchereau J.-L., Quignard J.-P., Joyeux J.-C., Tomasini J.-A., Structure du stock des géniteurs de la population de Pomatoschistus microps (Krøyer, 1838), (Gobiidæ), dans la lagune de Mauguio, France, Cybium 17, 1 (1993a) 11-13.

[14] Bouchereau J.-L., Quignard J.-P., Tomasini J.-A., Joyeux J.-C., Cycle sexuel, condition, fécondité et ponte de Pomatoschistus 
minutus (Poissons, Gobiidés) du Golfe du Lion, France, Cybium 14, 3 (1990c) 251-267.

[15] Bouchereau J.-L., Tomasini J.-A., Quignard J.-P., Joyeux J.-C., Stratégies et tactiques de reproduction de Pomatoschistus microps (Krøyer, 1838) et de Pomatoschistus minutus (Pallas, 1770) (Pisces, Gobiidæ) dans le golfe du Lion. Nids, déterminismes de la sédentarité et de la migration, Cybium 15, 4 (1991) 315-346.

[16] Cavinato P.G., Revisione dei Gobius della laguna veneta, Archeo. Oceanogr. Limnol. 7, 2/3 (1952) 157-212.

[17] CEMAGREF, Suivi de la salinité et de l'état trophique de l'élang de l'Or. Rapport de synthèse 1986-1988, Rapport pour le Service Maritime et de Navigation du Languedoc-Roussillon (1989) $37 \mathrm{p}$.

[18] Claridge P.N., Hardisty M.W., Potter P.C., Williams C.V., Abundance, life history and ligulosis in the gobies (Teleostei) in the inner Severn Estuary, J. Mar. Biol. Ass. U.K. 65, 4 (1985) 951-968.

[19] Clofnam, Check-list of the fishes of the north-eastern Atlantic and of the Mediterranean. (ed.) Hureau J.C., and Monod T., UNESCO, Presses Univ. France, Vol. I: 683 p. Vol. II (1973) $394 \mathrm{p}$.

[20] Creutzberg F., Fonds M., The seasonal variation in the distribution of some demersal fish species in the Dutch Wadden Sea, Thalassia Yougoslalvia 7, 1 (1971) 13-23.

[21] Cuguen J., Examen de l'évolution de la végétation de l'étang de Mauguio à partir de photographies aériennes. Rapport CERGA pour l'Association de Chasse Maritime des Sociétés Riveraines de l'Etang de l'Or (1980) 9 p.

[22] De Casabianca M.L., Kiener A., Gobiidés des étangs corses: systématique, écologie, régime alimentaire et position dans les chaînes trophiques, Vie Milieu A, 20, 3 (1969) 611-634.

[23] Doornbos G., Twisk F., Density, growth and annual food consumption of gobiid fish in the saline lake Grevelingen, the Netherlands, Neth. J. Sea Res. 21, 1 (1987) 45-74.

[24] Dunker G., T adiges W., Die Fische der Nordmark, Ahhand. Verhandl. Naturwiss. Vereins, Hamburg. N.F. Bd III. (Suppl.) (1960) $432 \mathrm{p}$.

[25] Evans S., Tallmark B., Seasonal dynamics of small vagile predators on a marine shallow soft bottom, Holarctic Ecol. 7, 2 (1984) 138-148.

[26] Fabi G., Froglia C., Food and feeding of Gobius niger L. in the Central Adriatic Sea, Proc. Verb. CIESM, 28, 5 (1983) 99102.

[27] Fabi G., Froglia C., A nole on the biology and fishery of the black goby (Gobius niger) in the Adriatic Sea, Fish Rep./FAO. Rapp. Pêches, 290 (1984) 167-170.

[28] Fabi G., Gianetti G., Growth parameters of the black goby (Gobius niger L.) in the Adriatic sea, based on otoliths reading, Rapp. Comm. int. Mer Médit. 29, 8 (1984) (1985) $87-90$.

[29] Fives J.M., Investigations of the plankton of the west coast of Ireland. - IV. Larval and post-larval stages of fish taken from the plankton of the west coast in surveys during the years 1958-1966, Proc. R. Ir. Acad., 70B (1970) 15-93.

[30] Fonds M., Seasonal abundance and vertebral variation of $P$. minutus. IIIe Symposium européen de Biologie marine, Arcachon, 2-7 septembre 1968 (1968).

[31] Fonds M., Remarks on the rearing of gobies. Pomatoschistus minutus and P. lozanoi, for experimental purposes, Helgol. Meeresunters 20 (1970) 620-628.

[32] Fonds M., The seasonal abundance and vertebral variation of Pomatoschistus minutus minutus and lozanoi (Gobiidæ) in the Dutch Wadden Sea, Vie Milieu 22 (suppl.) (1971) 393-408.

[33] Fouds M., Sand gobies in the Dutch Wadden Sea (Porratoschistus, Gobiidæ, Pisces), Neth. J. Sea Res. 6 (1973) 417-478.

[34] Fouda M., Miller P.J., $\Lambda$ ge and growth of the common goby, Pomatoschistus microps on the South Coast of England, Estuar. coast mar. Sci. 12, 2 (1981) 121-129.

[35] Georghiev Manolov J., Composition d'espèces et caractéristique des Gobiidés (Piscès) en Bulgarie, Proceedings of the Research Institute of Fisheries and Oceanography, Varna Tom (Vol.) VII (1966) 159-228.

[36) Gourret P., Les élangs saumâltes du Midi de la Franıce et leurs pêcheries, Ann. Mus. Hist. nat. Marseille, ser. zool., 5, 1 (1897) 1-386.

[37] Guitel F., Observations sur les mœurs de Gobius minutus, A.rch. Zool. exp. gén. ser. 2, 10 (1892) 499-555.

[38] Hamerlynck O., The identification of Pomatoschistus minutus (Pallas) and Pomatoschistus lozanoi (de Buen) (Pisces, Gobiidx), J. Fish Biol. 37, 5, (1990) 723-728.

[39] Hamerlynck O., Help C., Redant F., Life history, food consumption and resource partitioning in two sympatric gobies Pomatoschistus minutus and Pomatoschistus lozanoi in Belgian coastal waters. Intern. Council for the explor. of the Sea, C.M. 14 (mimeo) (1986).

[40] Hamerlynck O., Cattrijsse A., The food of Pomatoschistus minutus (Pisces; Gobiidæ) in the Belgian coastal waters, and a comparison with the food of its potential competitor $P$. lozanoi, J. Fish Biology 44 (1994) 53-771.

[41] Hass G., Variationstatistische Untersuchungen an Problem von Gobius microps, Schr. Naturw. Ver. Schl. Holst. 21, 3 (1936) 419-426.

[42] Hass G., Variabilitätstudien an Gobius niger L., Gobius minutus Pallas und Cottus scorpius L., Kieler Meeresforsch. 1, 2 (1937) 279-321

[43] Healey M.C., Gonad development and fecondity of the sand goby, Gobius minutus Pallas, Trans. Am. Fish. soc. 100, 3 (1971a) 520-526.

[44] Healey M.C., The distribution and abundance of sand gobies Gobius minutus in the Ythan esturary, I. Zool. Res. I ond. 163 (1971b) 177-229.

[45] Healey M.C., On the population ecology of the common goby in the Ythan estuary, J. Nat. Hist. 6 (1972) 133-145.

[46] Heincke F., Die Gobiidae und Syngnathidae der Ostsee nebst biologishen Bermerkungen. Arch. Naturgesch. 46 (1880) 301354. 
[47] Henard D., Vaulot D., Production primaire de l'étang de l'Or. DGRST, action concertée "étangs méditerranéens", Montpellier, 18 et 19 janvier 1979 (1979).

[48] Hervé P., Ichthyofaune comparée de deux étangs littoraux du Roussillon: Canet-St Nazaire et Salses-Leucate. Thèse $3^{\text {emre }}$ cycle, Univ. P.M. Curie, Paris, 253 p. (1978).

[49] Hesthagen I.H., Seasonal occurrence and lenth variation in the sand goby Pomatoschistus minutus (Pallas) in the inner Oslofjord, Norw. J. Zool. 23 (1975) 235-242.

[50] Hesthagen I.H., Migrations, breeding and growth in Pomatoschistus minutus (Pallas) (Pisces, Gobiidæ) in Oslofjorden, Norway, Sarsia 63 (1977) 17-26.

[51] Hesthagen I.H., Temperature and avoidance in the sand goby, Pomatoschistus minutus (Pallas), collected at different seasons, Env. Biol. Fish. 4 (1979) 369-377.

[52] Johnsen $S$, On the variation of Fishes in Relation to Environment. Bergens Mus. Ärb. 1936, Naturved. Rekke 4 (1936) $1-26$.

[53] Jones D., Miller P.J., Seasonal migrations of the common Goby Pomatoschistus microps (Kröyer), in Morecambe Bay and elsewhere, Hydrobiologia 27 (1966) 515-528.

[54] Joyeux J.-C., Bouchereau J.-L., Tomasini J.-A., Croissance et structure démographique de la population de Gobius niger Linné, 1758 (poisson, téléostéen) dans une lagune nord-méditerranéenne, Cah. Biol. mar. 32 (1991a) 415-437

[55] Joyeux J.-C., Bouchereau J.-L., Tomasini J.-A., La reproduction de Gobius niger (Pisces, Gobiidæ) dans la lagune de Mauguio, France. Rapports gonosomatiques, fécondités, ponte, xufs et larves, Vie Milieu 41, 2/3 (1991b) 97-107.

[56] Joyeux J.-C., Tomasini J.-A., Bouchereau J.-L., Le régime alimentaire de Gobius niger Linné, 1758 (Teleostei, Gobiidæ) dans la lagune de Mauguio, France, Ann. Sci. Nat., Zool. 13, 12 (1991c) 57-69.

[57] Joyeux J.-C., Tomasini J.-A, Bouchereau J.-L., Modalités de la reproduction de Gobius niger (Teleostei, Gobiidæ) dans une lagune méditerranéenne, Vie Milieu 42, 1 (1992) 1-13.

[58] Kunz Y., Salinity preference and salinity tolerance of the katadromous teleost Pomatoschistus (Gobius) microps, Krøyer, Proc. E. Ir. Acad. 68, 6 (1969) 77-88.

[59] Lawacz W., An analysis of variations in two populations of Gobius microps Kr. depending on the salinity of the habitat, Ekol. Pol. 13 (1965) 125-142.

[60] Lee S.C., Biology of the sand goby Pomatoschistus minutus (Pallas) (Teleostci: Gobioidea) in the Plymouth area, Ph. D. thesis, Bristol (1974)

[61] Le Menn F., Some aspects of vitellogenesis in a teleostean fish: Gobius niger, Comp. Biochem. Physiol. 62A (1974) 495-500.

[62] Lo Bianco S., Notizie biologische riguardanti specialmente il periodo di maturita sessuale degli animali del golfo di Napoli, Mitt. zool. Sta. Neapel 19 (1909) 513-761.

[63] Mankowski W., Badania planktonowe w Baltyku poludniowym w 1948 r, Biul. morsk. Inst. ryb. (1947).

[64] Mathias M.P., Dolique J., Sur les Gobiidæe du Bassin de Thau, Naturalia monspel. 4 (1962) 29-36.
[65] Miller P.J., Studies on the biology and taxinomy of British gobiid fishes, Ph.D. Thesis, Liverpool (1963).

[66] Miller P.J., The biology of the goby Pomatoschistus microps, Annu. Rep. Challenger Soc. 3, 16 (1964) 42-43.

[67] Miller P.J., Age structure and life-span in the common goby Pomatoschistus microps, J. Zool. Lond. 177 (1975) 425-448.

[68] Miller P.I., Adaptiveness and implications of small size in Teleosts, in: Fish Phenology: anabolic adaptiveness in Teleosts, Miller P.J. (ed.), Academic Press (1979) 263-305.

[69] Miller P.J., The tokology of gobiid fishes, in: Fish Reproduction: Strategies and Tactics (Potts G.W., Wootton R.J., (eds). London: Academic Press (1984) 119-153.

[70] Miller P.J., (1986) Gobioidei, in: Fishes of the North-eastern Atlantic and the Mediterranean". Vol. III, Whiteheat P.J.P., Bauchot M.L., Hureau J.-C., Nielsen J., Tortonese E. (ed.) UNESCO (1986) 1019-1085.

[71] Miller P. J., A new species of Didogobius (Teleostei: Gobiidæ) from the Adriatic Sea, J. Nat. Hist. 26, 6 (1992) 1413-1419.

[72] Moreira F., Costa J.L., Almeida P.R., Assis C., Costa M.J., Age determination in Pomatoschistus minutus (Pallas) and Pomatoschistus microps (Krøyer) (Pisces: Gobiidæ) from the upper Tagus estuary, Portugal, J. Fish Biol. 39 (1991) 433-440.

[73] Morawski M.S., Winter feeding of the sand goby (Pomatoschistus minutus Pallas) in relation to the depth in Gdansk Bay. Kiel, Meeresforsch. (Sonderheft), 4 (1978) 122-127.

[74] Muus B.J., The fauna of Danish Estuaries and Lagoons. Distribution and ecology of dominating species in the shallow reaches of the mesohaline zone, Meddr Danm. Fisk. og Havunders Ny serie, 5 (1967) 1-316.

[75] Nash R.D.M., Aspects of the biology of the black goby Gobius niger L., in: Oslofjorden, Norway, Sarsia 69 (1984) 55-61.

176] Nellbring S., A quantitative and experimental study of goby (Pomatoschistus spp.) nests on a shallow soft bottom. Northern Baltic Proper, Ophelia 25 (1986) 15-23

[77] Ninni E., I Gobius dei mari e della acque interne d'Italia, Memorie R Com. talassogr. ital. 242 (1938) 1-169.

[78] Nyman K.J., Observations on the behaviour of Gobius microps, Acta Soc. Fauna Flora fenn. 69, 5 (1953) 1-11.

[79] Padoa E., Sottordine Gobiiformes, Famiglia Gobiidx, in: "Uova, larve e stadi giovanili di Teleostei", Fauna Flora Golfo Napoli 38 (1953) 648-678.

[80] Pethon D., Leikutlingen i Øra-omrädet, Fauna, Oslo 28, 1 (1975) 23-30.

[81] Pons M., Etang de l'Or: étude d'ensemble du milieu saumâtre, de son environnement. Structure el dynanique des populations de Carcinus mediterraneus Czerniavski, 1884. Mém. Maîtrise Géographie, Montpellier III (1976) 111 p.

[82] Quignard J.-P., Bouchereau J.-L., Capape C., Joyeux J.-C., Tomasini J.A., Les débarquements des pềches aux Cabanes de Pérols (lagune de Mauguio), oct. 1985 - déc. 1988. Rap. Serv. Mar. et de Nav. Languedoc-Roussillon (1989) 84 p.

[83] Quignard J.-P., Mazoyer-Mayere C., Vianet R., Man-Wai R., Benharrat K., Un exemple d'exploitation lagunaire en Langue- 
doc: l'étang de l'Or (Mauguio). Pêche et production halieutique, Science pêche 336 (1983) 3-23.

[84] Ringuelet R., Les étangs du littoral languedocien: I: Scamandre-Thau. Ministère de la qualité de la vie, Serv. Protection des mers et des océans (1974) $51 \mathrm{p}$.

[85] Riouall R., Etude quantitative des algues macrophytes de substrat meuble de l'étang du Prévost (Hérault), Naturalia Monspeliensa sér. Bot., 26 (1976) 73-94.

[86] Shann R., Some notes on the life history and rate of growth in Gobius minutus, Ann. Mag. Nat. Hist. (8) 5 (1910) 217-239.

[87] Shih S.H., (1979) Pituitary structure and cycles of the common goby Pomatoschistus microps (Krøyer) (Teleostei: Gobiidx). Ph D. Thesis, University of Bristol.

[88] Sparta A., Uova e larve di Gobiidæ. III. Gobius ferrugineus Kolomb. Mem. M. Com. Talass. It. (1936) CCXXVIII.

[89] Stearns S.C., Crandall R.E., Plasticity for age and size at sexual maturity: a life history response to unvoiable stress, in: Fish reproduction: Siralegies and Taciics (G.W. Potts and R.J. Wootton, eds). London: Academic Press (1984) 13-33.

[90] Swedmark M., Variation de la croissance et dans la taille dans différentes populations du Téléostéen Gobius minutus. (Communication faite au Colloque de Biologie Marine à la Station Biologique de Roscoff, 1956). Ann. Biol. 33, 3-4 (1957) 163170 .

[91] Swedmark M., Sur la variation géographique de Gobius minutus, Pallas. I- Biologie et croissance, Arch. Zool. exp. gén., Notes et Revues 95 (10) (1958) 32-51.

[92] Swedmark M., Sur la variation géographique de Gobius minutus Pallas. II- Caractères morphologiques, chromatiques et numériques, Cah. Biol. mar. 9 (1968) 297-345.

[93] Taning V., Island-Faro-Omraadets Kutlinger (Gobiida). Videusk. Meddr. dansk naturh. Foren. 104 (1940) 267-282.

[94] Tomasini J.-A., Quignard J.P., Capape C., Bouchercau J.-L., (1991) Facteurs du succès reproductif de Syngnathus abaster Risso, 1826 (Pisces, Teleostei, Syngnathidæ) en milieu lagunaire méditerranéen (lagune de Mauguio, France), Acta (Ecol. 12,3 (1991) 331-355.
[95] Vaas K.F., Studies on the fish fauna of an estuary in the S.W. Netherlands, before and after its change into the stagnant, saline, I.ake Grevelingen, Hydrobinl. Bull 13 (1979) 177188.

[96] Vaas K.F., Vlasblom A.G., Koeijer P. De, Studies on the black goby (Gobius niger, Gobiidæ, Pisces) in the Veerse Meer, SW Netherlands, Neth. J. Sea Res. 9, 9 (1975) 56-68.

[97] Van der Gaag M., Aantallen, verdeling, groei en voedselop name van twee grondelsoorten op het Balgzand in 1975 en 1976, Intern Report $n^{\circ}$ 1977-9, Neth. Inst. Sea Res. Texel, (1979) $80 \mathrm{p}$.

[98] Vasileva E.D., Differenciation of Caucasian gobies, presently grouped in the subspecies Neogobius platyrostris constructor (Gobiidæ), based on an analysis of museum collections; Vopr. Ikhtiol. 34, 6, 622-633 (J. Ichthyol., 1995, 35, 1:1-20), (1994).

[99] Vasileva E.D., Vasilev V.P., Systematics of Caucasian freshwater gobies (Gobiid $x$ ) in the light of contemporary data, with a description of a new species, Neogobius rhodioni. Vopr. Ikhtiol., 34, 6:747-758 (J. Ichthyol. 1995, 35, 2: 139-142) (1995).

[100] Vasileva E.D., Vasilev V.P., Pinchuk V.I., A craniological analysis of gobies of the Pontioscola Iljin, 1927. I- A comprative morphological investigation of Neogobius cephalargoides and other forms of gobies assigned to the species $N$. platyrostris (Gobiidæ). Vopr. Ikhtiol. 33, 1:25-36 (J. Ichthyol. 1993, 5 (1993) 108-123).

[101] Vesey G., Langford T.E., The biology of the black goby, Gobius niger L., in an English south-coast bay, J. Fish Biol. 27 (1985) 417-429.

[102] Wahlbcrg B., Gobies, Zool. Rcvy 31 (1969) 36-37.

[103] Webb C.J., Systematics of the Pomatoschistus minutus complex (Teleostei: Gobiodei). Philos. Trans. R. Soc. Lond., ser B, 291 (1980) 201-241.

[104] Webb C.J., Karyology of Pomatoschistus microps (Telostei: Gobiodei). J. Mar. Biol. Ass. U.K. 66 (1986) 259-266.

[105] Wheeler A., The fishes of British Isles and North-West Europe. Mac Millan Ed., London-Melbourne-Toronto (1969) $613 \mathrm{p}$. 